\section{Simultaneous Determination of Azimsulfuron, Flazasulfuron and Halosulfuron-methyl in Grains, Seeds, Vegetables and Fruits by HPLC}

\author{
Susumu Ishimitsu,* Akiko Kaihara, \\ Kimihiko Yoshii, Yukari Tsumura, \\ Yumiko Nakamura, and Yasuhide Tonogai
}

National Institute of Health Sciences, Osaka Branch, Division of Food Chemistry, 1-1-43 Hoenzaka, Chuo-ku, Osaka 5400006, Japan

(Received January 16, 2002; Accepted May 27, 2002)

A method was developed for the simultaneous determination of 3 sulfonylurea herbicides, azimsulfuron, flazasulfuron and halosulfuron-methyl in agricultural products. The herbicides were extracted with acetone, re-extracted with ethyl acetate, and then transferred to $2 \%$ dipotassium hydrogenphosphate solution. The herbicides were extracted again into ethyl acetate and cleaned up using Sep-Pak ${ }^{\circledR}$ Plus Alumina $\mathrm{N}$ and Bond Elut $^{\circledR}$ SAX cartridge columns. The 3 sulfonylurea herbicides were determined by HPLC. The fortified peaks were confirmed by LC/MS with electrospray ionization (ESI), and the peaks of azimsulfuron, flazasulfuron and halosulfuron-methyl were determined. The recoveries of the 3 sulfonylurea herbicides from brown rice, corn, cotton seed, ginkgonut, chestnut, almond, walnut, cucumber, pumpkin, orange, grapefruit, mandarin, lemon and grape ranged from 77.0 to $112.3 \%$ following fortification at $0.05-0.5 \mu \mathrm{g} / \mathrm{g}$. The detection limits were $0.01 \mu \mathrm{g} / \mathrm{g}$ for azimsulfuron and halosulfuronmethyl, and $0.02 \mu \mathrm{g} / \mathrm{ml}$ for flazasulfuron(S/N > 3).

Key words — sulfonylurea herbicide, HPLC, Sep-Pak ${ }^{\circledR}$ Plus Alumina N, Bond Elut ${ }^{\circledR}$ SAX

\section{INTRODUCTION}

Sulfonylurea herbicides are a relatively new class of compounds whose herbicidal activity was discov-

*To whom correspondence shold be addressed: National Institute of Health Sciences, Osaka Branch, Division of Food Chemistry, 1-1-43, Hoenzaka, Chuo-ku, Osaka 540-0006, Japan. Tel.: +81-6-6941-1533; Fax: +81-6-6942-0716; E-mail: ishimits@nihs.go.jp ered in the mid-1970s. ${ }^{1)}$ They show high activity at low application levels and low mammalian toxicity; at least 16 sulfonylurea herbicides are currently on the market around the world. ${ }^{2)}$ The Ministry of Health, Labour and Welfare (MHLW) in Japan has already specified the tolerance levels for residual sulfonylurea herbicides such as azimsulfuron, bensulfuron-methyl, chlorimuron-ethyl, chlorsulfuron, flazasulfuron, imazasulfuron metsulfuronmethyl and tribenuron-methyl. The MHLW intends to set the maximum residue limits (MRL) and the official analytical method for halosulfuron-methyl in agricultural products. The official analytical methods for pesticides under the Foof Sanitation Law are mostly individual determinations. We have attempted the simultaneous determination of 9 sulfonylurea herbicides including halosulfuron-methyl; however, some of them showed low recoveries, which may be caused by their low solubility in aqueous solution or insufficient recoveries from the cleanup columns. Few studies have reported on the analysis of multiple sulfonylurea herbicides in agricultural products by HPLC-photodiode array detection ${ }^{3)}$ and capillary electrophoresis. ${ }^{4,5)}$

The MHLW has already set the MRL in agricultural products for 229 pesticides under the Food Sanitation Law. ${ }^{6}$ Among them, we have reported the HPLC determination of the official analytical method for emamectin ${ }^{7)}$ and clethodim ${ }^{8)}$ in agricultural products.

In the present study, the simultaneous determination of azimsulfuron and flazasulfuron, which have been in effect since November 22, 1999, ${ }^{9)}$ and halosulfuron-methyl in agricultural products was conducted. Recently, the MHLW has set the MRL and the official analytical method for azimsulfuron, flazasulfuron and halosulfuron-methyl in agricultural products. ${ }^{\text {) }}$

\section{MATERIALS AND METHODS}

Samples — Brown rice, corn, ginkgonut, chestnut, almond, walnut, cucumber, pumpkin, orange, grapefruit, mandarin, lemon and grape were purchased from markets in Osaka, Japan. The cotton seeds were provided by MHLW.

\section{Reagents -}

Acetone, acetonitrile, $n$-hexane, methanol and ethyl acetate: Pesticide residue analytical grade (Wako Pure Chemical Industries, Ltd., Osaka, Japan). 


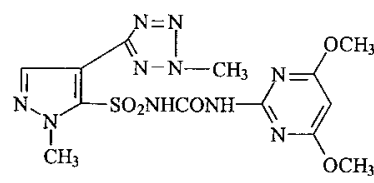

Azimusulfuron

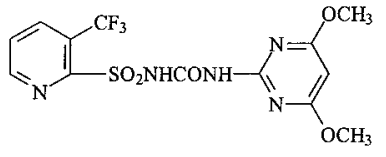

Flazasulfuron

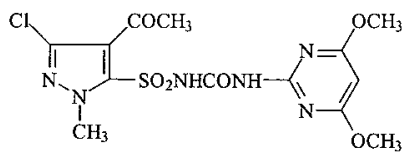

Halosulfuron-methyl

Fig. 1. Chemical Structures of Azimsulfuron, Flazasulfuron and Halosulfuron-methyl

Hydrochloric acid, dipotassium hydrogenphosphate, diatomaceous earth Celite 545, sodium chloride, trichloroacetic acid and sodium sulfate: Special grade (Wako Pure Chemical Industries).

Sodium sulfate: Activated at $120^{\circ} \mathrm{C}$ for $12 \mathrm{hr}$.

Standard materials: Azimsulfuron, flazasulfuron and halosulfuron-methyl were obtained from Wako Pure Chemical Industries. The chemical structures of these compounds are shown in Fig. 1.

Pesticide standard solution: Standard solutions of azimsulfuron, flazasulfuron and halosulfuronmethyl $(1000 \mu \mathrm{g} / \mathrm{ml})$ were prepared by dissolving each pesticide in acetonitrile. For the recovery experiments, the standard solution was diluted with acetonitrile $(10 \mu \mathrm{g} / \mathrm{ml})$.

HPLC and liquid chromatography/mass spectrometry $(L C / M S)$ : Mobile phase A, $0.01 \%$ trichloroacetic acid in distilled water; mobile phase $\mathrm{B}$, acetonitrile.

Cartridge columns: Bond Elut ${ }^{\circledR}$ SAX cartridge column (Varian, Harbor City, CA, U.S.A.). Sep-Pak ${ }^{\circledR}$ Plus Alumina N cartridge column (Waters Corp., Milford, MA, U.S.A.). Electric homogenizer (Nihonseik, Tokyo, Japan). Rotary evaporator (Shibata Scientific Technology, Tokyo, Japan).

\section{HPLC and LC/MS Analysis}

Apparatus: The HPLC and LC/MS used in our previous study. ${ }^{8)}$

Operating parameters of HPLC: The mobile phase flow rate was adjusted to $1.0 \mathrm{ml} / \mathrm{min}$ during the analysis. The system was equilibrated at $20 \%$ mobile phase B in mobile phase A; a 15 min linear gradient to $100 \%$ mobile phase $B$ was begun and held for $5 \mathrm{~min}$. When the gradient was completed, the mobile phase was returned to $80 \% \mathrm{~A}, 20 \% \mathrm{~B}$ and held for $7 \mathrm{~min}$ to re-equilibrate the column. The other conditions were as follows: temperature for column separation, $40^{\circ} \mathrm{C}$, and ultraviolet detection wavelength, $245 \mathrm{~nm}$.

Operating parameters of $L C / M S$ : The stainless steel column $(2.0 \mathrm{~mm}$ i.d. $\times 100 \mathrm{~mm})$ was packed with Tosoh TSKgel Super-ODS. The mobile phase flow rate was adjusted to $0.2 \mathrm{ml} / \mathrm{min}$ during the analysis. The system was equilibrated at $20 \%$ mobile phase B in mobile phase A; a 12-min linear gradient to $100 \%$ mobile phase $B$ was begun and held for $3 \mathrm{~min}$. The other chromatographic conditions were as described for the operating parameters of the HPLC.

MS conditions: Analytical mode, electrospray ionization (ESI negative); drying gas $\left(\mathrm{N}_{2}\right)$ flow, $4.5 \mathrm{l} /$ $\mathrm{min}$; probe voltage, $-4.5 \mathrm{kV}$. The selected ion for monitoring was $\mathrm{m} / \mathrm{z} 423$ for azimsulfuron, 406 for flazasulfuron and 433 for halosulfuron-methyl.

Extraction — Ten g of shredded sample (brown rice, corn, cotton seed, ginkgonut, chestnut, almond, walnut) was placed in a stainless steel cup to which $20 \mathrm{ml}$ of water was added and allowed to stand for $2 \mathrm{hr}$, and then $100 \mathrm{ml}$ of acetone was added. Twenty $\mathrm{g}$ of chopped cucumber, pumpkin, orange, grapefruit, mandarin, lemon or grape was placed in a stainless steel cup to which $100 \mathrm{ml}$ of acetone was added. The mixture was homogenized for $3 \mathrm{~min}$ and then filtered through filter paper with $7 \mathrm{~g}$ of Celite 545 (10 mm thickness) into a 300-ml round-bottom flask. The extract was rinsed, filtered with $50 \mathrm{ml}$ acetone, and evaporated to dryness with a rotary evaporator. The extract was transferred to a $200-\mathrm{ml}$ beaker, to which was added $100 \mathrm{ml}$ of $10 \%$ sodium chloride solution and then adjusted to $\mathrm{pH} 3-4$ with $1 \mathrm{~mol} / \mathrm{l}$ of 
hydrochloric acid. The extract was transferred to a 300-ml separatory funnel, $50 \mathrm{ml}$ ethyl acetate added, and vigorously shaken for $5 \mathrm{~min}$. Another $50 \mathrm{ml}$ of ethyl acetate was added, and the solution was shaken again for $5 \mathrm{~min}$. The organic layers were collected in a $300-\mathrm{ml}$ separatory funnel, $100 \mathrm{ml}$ of $n$-hexane and $50 \mathrm{ml}$ of $2 \%$ dipotassium hydrogenphosphate solution added, and vigorously shaken for $5 \mathrm{~min}$. Another $50 \mathrm{ml}$ of $2 \%$ dipotassium hydrogenphosphate solution was added, and the solution was again shaken for $5 \mathrm{~min}$. The aqueous layers were collected in a 200-ml beaker and then adjusted to pH 3-4 with $6 \mathrm{~mol} / \mathrm{l}$ of hydrochloric acid. The extract was transferred to a 300-ml separatory funnel, $50 \mathrm{ml}$ of ethyl acetate added, and vigorously shaken for $5 \mathrm{~min}$. Another $50 \mathrm{ml}$ of ethyl acetate was added, and the solution was again shaken for $5 \mathrm{~min}$. The organic layers were collected in a 300-ml Erlenmeyer flask, dehydrated with $c a .20 \mathrm{~g}$ of anhydrous $\mathrm{Na}_{2} \mathrm{SO}_{4}$, and allowed to stand for $30 \mathrm{~min}$. They were then filterd through filter paper to separate the anhydrous $\mathrm{Na}_{2} \mathrm{SO}_{4}$.

The flask was then rinsed with an additional $20 \mathrm{ml}$ of ethyl acetate and evaporated to dryness under vacuum at $40^{\circ} \mathrm{C}$.

\section{Cleanup}

Procedure A: A Sep-Pak ${ }^{\circledR}$ Plus Alumina N cartridge column was conditioned with $10 \mathrm{ml}$ of acetonitrile before use. The residue was dissolved in $5 \mathrm{ml}$ of acetonitrile and charged onto the column. The column was rinsed with $10 \mathrm{ml}$ acetonitrile, followed by elution with $15 \mathrm{ml}$ of $20 \%$ water in acetonitrile, and the eluate was evaporated to dryness under vacuum at $40^{\circ} \mathrm{C}$. The residue was dissolved in $30 \mathrm{ml}$ of ethyl acetate and transffered to a 100-ml Erlenmeyer flask, dehydrated with $c a .20 \mathrm{~g}$ of anhydrous $\mathrm{Na}_{2} \mathrm{SO}_{4}$, and allowed to stand for $30 \mathrm{~min}$. The solution was then filtered through filter paper to separate the anhydrous $\mathrm{Na}_{2} \mathrm{SO}_{4}$. The flask was then rinsed with an additional $20 \mathrm{ml}$ of ethyl acetate, and filtered through filter paper. The solution was evaporated to dryness under vacuum at $40^{\circ} \mathrm{C}$.

Procedure B: A Bond Elut ${ }^{\circledR}$ SAX cartridge column was conditioned with $10 \mathrm{ml}$ of $25 \% n$-hexane in acetone before use. The residue was dissolved in $5 \mathrm{ml}$ of $25 \% n$-hexane in acetone and charged onto the column. The column was rinsed with $10 \mathrm{ml}$ of $25 \% n$-hexane in acetone, followed by elution with $15 \mathrm{ml}$ of $10 \%$ methanol in acetone. The eluate was evaporated to dryness under vacuum at $40^{\circ} \mathrm{C}$ and dissolved in $1 \mathrm{ml}$ of acetonitrile.

Quantification —— The sample solution was au-

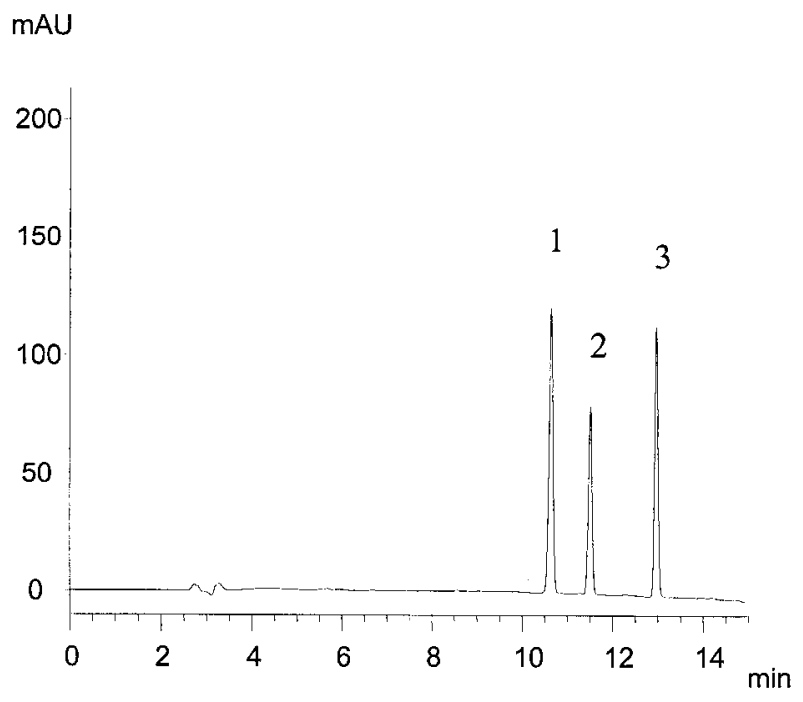

Fig. 2. HPLC Chromatogram of Azimsulfuron, Flazasulfuron and Halosulfuron-methyl

Peaks: 1 = Azimsulfuron ; 2 = flazasulfuron ; 3 = halosulfuronmethyl. Twenty $\mu$ l of a solution containing approximately by $2 \mu \mathrm{g} / \mathrm{ml}$ of each pesticide compounds was injected.

tomatically injected into the HPLC system for residue analysis. The concentration of azimsulfuron, flazasulfuron and halosulfuron-methyl was calculated based on a peak area calibration curve. The injection was performed three times for each sample to test the reproducibility.

Recovery Test — Chopped samples were fortified with $0.05-0.5 \mu \mathrm{g} / \mathrm{g}$ azimsulfuron, flazasulfuron and halosulfuron-methyl and analyzed by the proposed method. The recovery data represent 5 replications.

\section{RESULTS AND DISCUSSION}

\section{HPLC Chromatogram, Linearity and Limit of Detection}

An HPLC chromatogram of the standards is shown in Fig. 2. The retention times of azimsulfuron, flazasulfuron and halosulfuron-methyl are 10.6, 11.5 and $13.0 \mathrm{~min}$, respectively. In the present study, trichloroacetic acid was used as the ion-pair reagent, whereas 1-heptanesulfonic acid could not be used because azimsulfuron, flazasulfuron and halosulfuron-methyl were not eluted from the column.

The linear dynamic range of the detector response at $245 \mathrm{~nm}$ for azimsulfuron, flazasulfuron and halosulfuron-methyl was examined and appeared to be from 0.05 to $4 \mu \mathrm{g}$ injected on-column. The detection limits were $0.01 \mu \mathrm{g} / \mathrm{ml}$ for azimsulfuron and 
Table 1. Transfer of Sulfonylurea Herbicides from Ethyl Acetate Layer to Potassium Hydrogenphosphate Layer by the Addition of $n$-Hexane

\begin{tabular}{cccc}
\hline \hline & \multicolumn{3}{c}{ Transfer(\%, mean \pm S.D. $)^{a)}$} \\
\cline { 2 - 4 } Added volume of $n$-hexane(ml) & Azimsulfuron & Flazasulfuron & Halosulfuron-methyl \\
\hline $0 \mathrm{ml}$ & $98.8 \pm 3.4$ & $97.3 \pm 2.8$ & $50.0 \pm 3.1$ \\
$50 \mathrm{ml}$ & $97.1 \pm 3.8$ & $96.6 \pm 3.3$ & $72.7 \pm 3.8$ \\
$100 \mathrm{ml}$ & $96.5 \pm 3.3$ & $95.3 \pm 3.4$ & $97.7 \pm 3.5$ \\
\hline
\end{tabular}

a) Average \pm standard deviation of 5 determinations. A $0.5 \mu \mathrm{g}$ portion of each sulfonylurea herbicide was added to $100 \mathrm{ml}$ of ethyl acetate and some $n$-hexane and $50 \mathrm{ml}$ of $2 \%$ potassium hydrogenphosphate solution and shaken vigorously for $5 \mathrm{~min}$. Another $50 \mathrm{ml}$ of $2 \%$ potassium hydrogenphos- phate solution was added, and the solution was again shaken for $5 \mathrm{~min}$. The aqueous layers were collected and then adjusted to pH 3-4 with $6 \mathrm{~mol} / \mathrm{l}$ of hydrochloric acid. The aqueous layer was added to $50 \mathrm{ml}$ of ethyl acetate and shaken vigorously for $5 \mathrm{~min}$. Another $50 \mathrm{ml}$ of ethyl acetate was added, and the solution was shaken again for $5 \mathrm{~min}$. The organic layers were collected, evaporated to drynes under vacuum at $40^{\circ} \mathrm{C}$, and dissolved in $1 \mathrm{ml}$ of acetonitrile.

halosulfuron-methyl and $0.02 \mu \mathrm{g} / \mathrm{ml}$ for flazasulfuron $(\mathrm{S} / \mathrm{N}>3)$.

\section{Extraction}

Azimsulfuron, flazasulfuron and halosulfuronmethyl in agricultural products were extracted with acetone.

The official analytical method for azimsulfuron and flazasulfuron ${ }^{9)}$ used $2 \%$ dipotassium hydrogenphosphate solution for the extraction from ethyl acetate into the aqueous layer. However, the recovery of halosulfuron-methyl was approximately 50\%, which may be due to its low solubility in aqueous solution. The result is shown in Table 1. The addition of $100 \mathrm{ml}$ of $n$-hexane to ethyl acetate layer before shaking with $2 \%$ dipotassium hydrogenphosphate allowed for good recovery of the halosulfuron-methyl. This result indicated that the simultaneous determination of the 3 sulfonylurea herbicides prepared by the official analytical method for azimsulfuron and flazasulfuron ${ }^{9}$ was employed with slight modification.

\section{Cleanup}

The official analytical method for azimsulfuron and flazasulfuron ${ }^{9)}$ used an alumina open column and Bond Elut ${ }^{\circledR}$ SAX for sample purification. The alumina open column and Sep-Pak ${ }^{\circledR}$ Plus Alumina N cartridge column were compared for recoveries and cleaning up the extract. Almost the same recoveries were obtained, and the use of the alumina open column is more time-consuming for sample preparation. However, the cleanup was not satisfactory with this column; therefore, a second cleanup with another column was necessary. We evaluated the use of ion exchange cartridge columns such as Bond Elut $^{\circledR}$ SAX, PRS, NH2, SCX, and PSA cartridge columns for sample purification. The Bond Elut ${ }^{\circledR}$

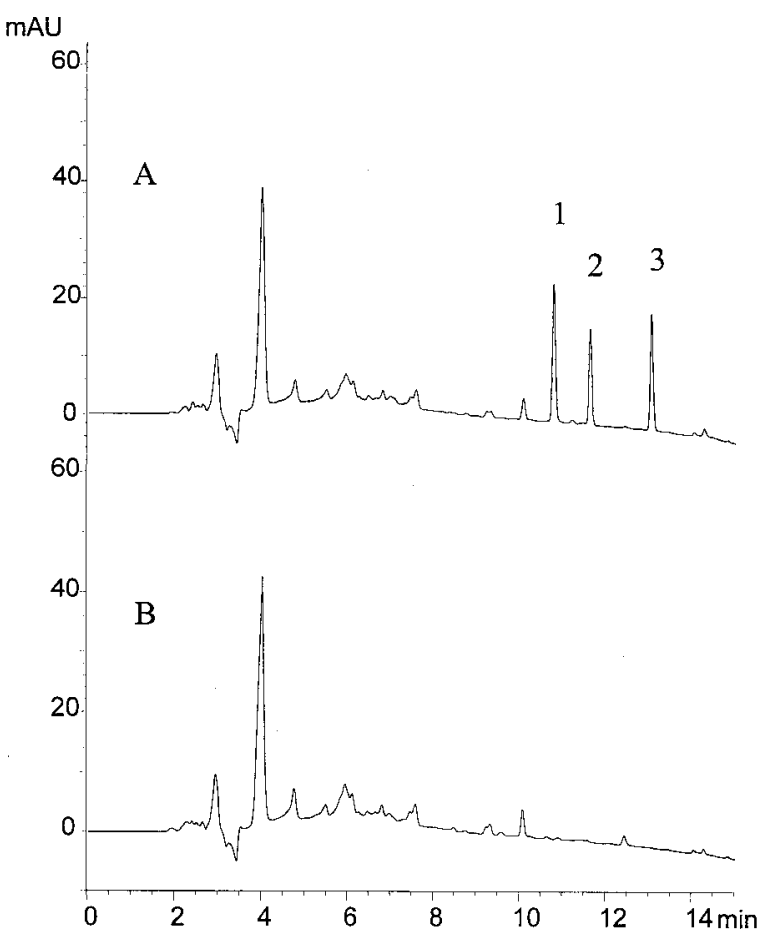

Fig. 3. Typical HPLC Chromatograms of Agricultural Product Samples

Peaks: 1 = Azimsulfuron; $2=$ flazasulfuron; $3=$ halosulfuronmethyl. Chromatograms are almond-fortified to $0.2 \mu \mathrm{g} / \mathrm{g}(\mathrm{A})$ and the almond blank(B).

SAX cartridge column gave the best recovery among them. This result indicated that the same column gave satisfactory recoveries with the official analytical method for azimsulfuron and flazasulfuron ${ }^{9)}$ and our analytical method.

Typical chromatograms of an almond-fortified $0.2 \mu \mathrm{g} / \mathrm{g}$ (A) sample of the three pesticides and an almond blank (B) are shown in Fig. 3. The HPLC chromatogram of the sample solution of cotton seed shows an interfering peak close to the retention time of flazasulfuron after cleanup with 2 cartridge col- 

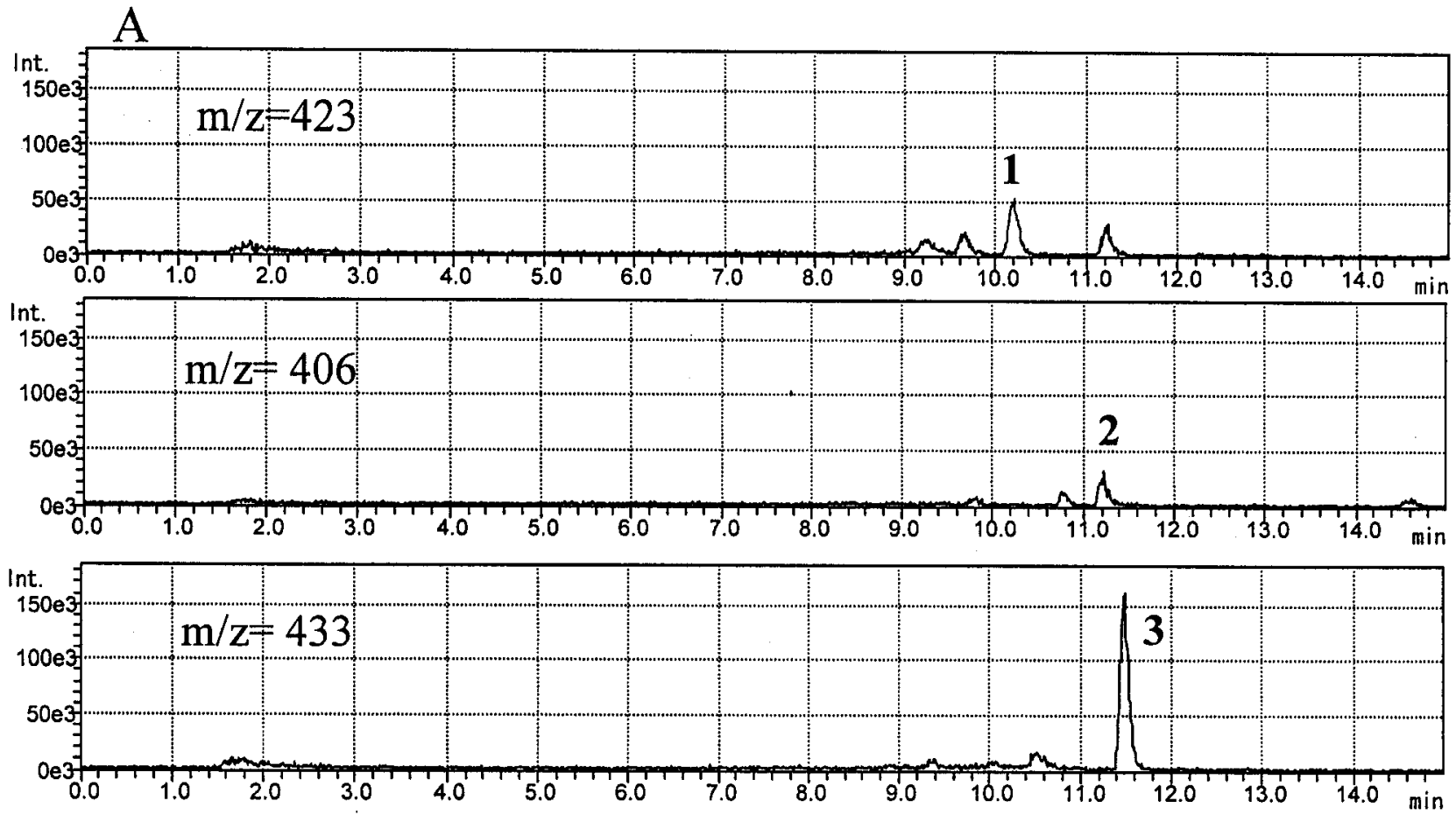

$\mathrm{B}$
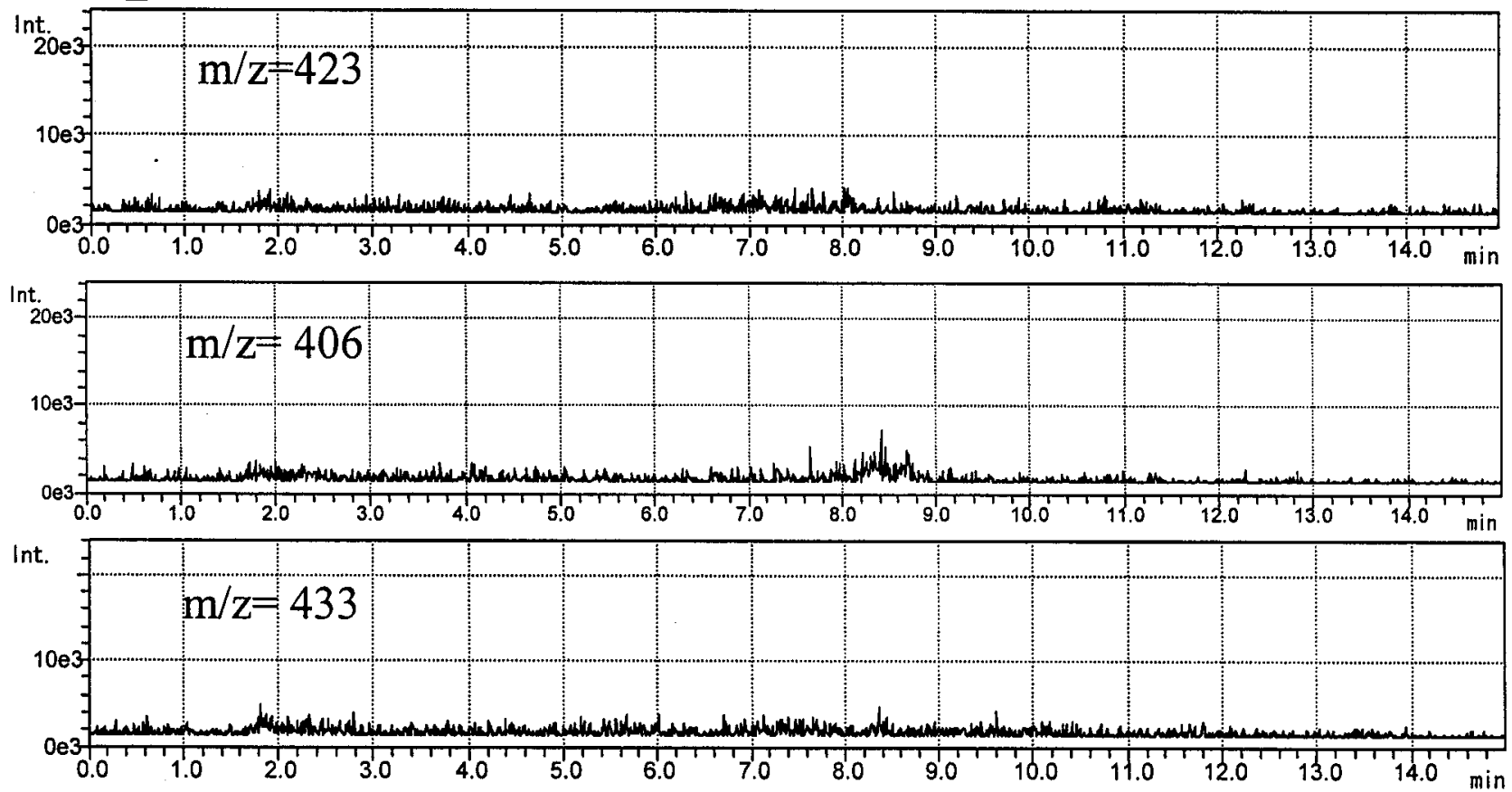

Fig. 4. Selected Ion Monitoring (SIM) Chromatograms of Agricultural Product Samples by LC/MS (ESI)

Peaks: 1 = Azimsulfuron; 2 = flazasulfuron; 3 = halosulfuron-methyl. SIM chromatograms are almond-fortified to $0.2 \mu \mathrm{g} / \mathrm{g}(\mathrm{A})$ and the almond blank(B).

umns. UV detection is commonly used for pesticide residue analysis by HPLC. However, an agricultural product sample shows many interference peaks in the UV detection. The detected peaks in the samples were then confirmed by LC/MS (ESI). The selected ion modes for monitoring were $\mathrm{m} / \mathrm{z} 423$ for azimsulfuron, $\mathrm{m} / \mathrm{z} 406$ for flazasulfuron and $\mathrm{m} / \mathrm{z} 433$ for halosulfuron-methyl. Figure 4 shows an almondfortified $0.2 \mu \mathrm{g} / \mathrm{g}$ (A) sample and an almond blank (B) by LC/MS (SIM). The peak of azimsulfuron, flazasulfuron and halosulfuron-methyl in almond blank was not detected. The result indicated that 
Table 2. Recoveries of Azimsulfuron, Flazasulfuron and Halosulfuron-methyl Added to Agricultural Products

\begin{tabular}{|c|c|c|c|c|}
\hline \multirow[b]{2}{*}{ Sample } & \multirow{2}{*}{$\begin{array}{l}\text { Fortified level } \\
(\mu \mathrm{g} / \mathrm{g})\end{array}$} & \multicolumn{3}{|c|}{ Recovery $(\%, \text { mean } \pm \text { S.D. })^{a)}$} \\
\hline & & Azimsulfuron & Flazasulfuron & Halosulfuron-methyl \\
\hline Brown rice & 0.05 & $84.0 \pm 5.3$ & $87.3 \pm 5.0$ & $90.7 \pm 3.1$ \\
\hline Corn & 0.05 & $83.7 \pm 7.1$ & $90.7 \pm 5.5$ & $95.0 \pm 1.7$ \\
\hline Cotton seed & 0.05 & $88.3 \pm 3.5$ & $112.3 \pm 2.5$ & $94.7 \pm 3.1$ \\
\hline Ginkgonut & 0.05 & $88.3 \pm 3.8$ & $88.7 \pm 4.0$ & $93.0 \pm 1.7$ \\
\hline Chestnut & 0.05 & $92.3 \pm 4.0$ & $85.3 \pm 4.0$ & $92.3 \pm 1.5$ \\
\hline Walnut & 0.05 & $86.0 \pm 5.3$ & $87.7 \pm 1.5$ & $87.0 \pm 5.3$ \\
\hline Almond & 0.2 & $85.0 \pm 5.2$ & $86.3 \pm 1.2$ & $89.7 \pm 1.5$ \\
\hline Cucumber & 0.5 & $80.9 \pm 1.3$ & $83.3 \pm 5.2$ & $88.4 \pm 4.3$ \\
\hline Pumpkin & 0.5 & $77.0 \pm 3.5$ & $83.3 \pm 4.4$ & $90.6 \pm 4.1$ \\
\hline Orange & 0.1 & $87.7 \pm 5.1$ & $89.0 \pm 4.0$ & $92.3 \pm 2.5$ \\
\hline Grapefruit & 0.1 & $83.0 \pm 4.4$ & $87.7 \pm 4.5$ & $88.7 \pm 5.1$ \\
\hline Mandarin & 0.1 & $81.0 \pm 2.0$ & $83.4 \pm 4.5$ & $91.0 \pm 5.3$ \\
\hline Lemon & 0.1 & $80.0 \pm 2.0$ & $83.3 \pm 4.2$ & $88.7 \pm 2.1$ \\
\hline Grape & 0.1 & $89.0 \pm 1.0$ & $90.3 \pm 3.8$ & $86.3 \pm 2.5$ \\
\hline
\end{tabular}

a) Average \pm standard deviation of 5 determinations.

when measuring pesticides in agricultural products including many interfering peaks on UV detection, using the SIM of LC/MS significantly improved the qualitative analyses.

\section{Recovery Test}

The recoveries of azimsulfuron, flazasulfuron and halosulfuron-methyl in 14 agricultural products fortified at $0.05-0.5 \mu \mathrm{g} / \mathrm{g}$ are shown in Table 2 . In Japan, the common acceptable range of recovery for pesticide residue is $70-120 \%$. The recoveries of azimsulfuron, flazasulfuron, and halosulfuron-methyl were $77.0-92.3 \%, 83.3-112.3 \%$ and $86.3-$ $95.0 \%$, respectively. The CV of the recovery was within $10 \%$.

\section{REFERENCES}

1) Hickes, H. and Watrous, M. (1999) Multiresidue method for determination of sulfonylurea herbicides in water by liquid chromatography with confirmation by capillary electrophoresis. J. AOAC Int., 82, 15231533.

2) Dinelli, G., Vicari, A. and Catizone, P. (1993) Use of capillary electrophoresis for detection of metsulfuron and chlorsulfuron in tap water. J. Agric. Food Chem., 41, 742-746.
3) Takatsuki, S., Nemoto, S., Matsuda, R., Sasaki, K. and Toyoda, M. (1999) Determination of 21 pesticides in agricultural products by HPLCphotodiode array detection. J. Food Hyg. Soc. Japan, 40, 315-319.

4) Krynitsky, A. J. and Swineford, D. M. (1995) Determination of sulfonylurea herbicides in grans by capillary electrophoresis. J. AOAC Int., 78, 10911096.

5) Nemoto, S. and Lehotay, S. J. (1998) Analysis of multiple herbicides in soybeans using pressurized liquid extraction and capillary electrophoresis. $J$. Agric. Food Chem., 46, 2190-2199.

6) Announcement No. 94 (2002) Ministry of Health, Labour and Welfare, Japan.

7) Yoshii, K., Kaihara, A., Tsumura, Y., Ishimitsu, S. and Tonogai, Y. (2001) Simultaneous determination of residue of emamectin and its metabolites, and milbemectin, ivermectin, and abamectin in crops by liquid chromatography with fluorescence detection. J. AOAC Int., 84, 910-917.

8) Ishimitsu, S., Kaihara, A., Yoshii, K., Tsumura, Y., Nakamura, Y. and Tonogai, Y. (2001) Deterrmination of clethodim and its oxidation metabolites in crops by liquid chromatography with confirmation by LC/ MS. J. AOAC Int., 84, 1172-1178.

9) Announcement No. 237 (1999) Ministry of Health and Welfare, Japan. 